\title{
Cook Islands
}

National Cancer Institute

\section{Source}

National Cancer Institute. Cook Islands. NCI Thesaurus. Code C16469.

A group of islands in the South Pacific Ocean, east of Australia, between Tonga and French Polynesia. 